\title{
MILK AND HONEY
}


This page intentionally left blank. 


\title{
Milk and Honey
}

\author{
Essays on Ancient Israel and the Bible \\ in Appreciation of the Judaic Studies Program \\ at the University of California, San Diego
}

\section{Edited by}

Sarah Malena and David Miano

Winona Lake, Indiana

EISENBRAUNS

2007 
(C) Copyright 2007 by Eisenbrauns.

All rights reserved.

Printed in the United States of America.

www.eisenbrauns.com

\section{Cataloging in Publication Data}

Milk and honey : essays on ancient Israel and the Bible in appreciation of the Judaic Studies Program at the University of California, San Diego / edited by Sarah Malena and David Miano.

p. $\mathrm{cm}$.

ISBN 978-1-57506-127-6 (hardcover : alk. paper)

1. Bible. O.T.-Criticism, interpretation, etc. 2. Bible. O.T.-

Language, style. 3. Bible. O.T.-Antiquities. I. Malena, Sarah.

II. Miano, David. III. University of California, San Diego. Judaic Studies Program.

BS1171.3.M55 2007

$221.6-\mathrm{dc} 22$

The paper used in this publication meets the minimum requirements of the American National Standard for Information Sciences-Permanence of Paper for Printed Library Materials, ANSI Z39.48-1984.@ ${ }^{\mathrm{TM}}$ 